\title{
Identification of Burkholderia cepacia complex pathogens by rapid-cycle PCR with fluorescent hybridization probes
}

Correspondence
Ivo Steinmetz
steinmetz.ivo@uni-greifswald.de

Received 7 December 2005

Accepted 17 February 2006

\author{
Ralf-Peter Vonberg, ${ }^{1}$ Susanne Häußler, ${ }^{1,2}$ Peter Vandamme ${ }^{3}$ \\ and Ivo Steinmetz ${ }^{1,4}$
}

\author{
${ }^{1}$ Institute of Medical Microbiology and Hospital Epidemiology, Medical School Hannover, \\ Carl-Neuberg-Strasse 1, 30625 Hannover, Germany \\ ${ }^{2}$ Department of Cell Biology, German Research Center for Biotechnology, Braunschweig, \\ Germany \\ ${ }^{3}$ Laboratorium voor Mikrobiologie, Universiteit Gent, Belgium \\ ${ }^{4}$ Friedrich Loeffler Institute of Medical Microbiology, Ernst Moritz Arndt University Greifswald, \\ Germany
}

\begin{abstract}
Members of the Burkholderia cepacia complex are important bacterial pathogens in cystic fibrosis (CF) patients. The B. cepacia complex currently consists of nine genetic subgroups (genomovars) of different epidemiological relevance and possibly of different pathogenic potential in humans. In this study, a new approach was developed for the rapid identification of B. cepacia genomovar I, Burkholderia multivorans (genomovar II), Burkholderia cenocepacia (lineage III-A and III-B), Burkholderia stabilis (genomovar IV) and Burkholderia vietnamiensis (genomovar V), which cause the large majority of infections in CF patients. The method was based on the detection of differences in the $\operatorname{rec} A$ gene sequence by using rapid-cycle PCR and genomovar-specific fluorescence resonance energy transfer (FRET) probes. The genomovar status of all $39 \mathrm{~B}$. cepacia complex strains tested (genomovars I-V) was identified by melting-curve analysis. Each FRET probe produced a specific fluorescence signal only with the respective genomovar, and not with other B. cepacia complex strains and Burkholderia spp. The identification system was easy to handle and revealed $B$. cepacia complex genomovar I-V status from culture isolates within about $1 \mathrm{~h}$.
\end{abstract}

\section{INTRODUCTION}

Burkholderia cepacia, first described by Burkholder as the cause of soft rot in onions, is commonly found throughout the environment and causes opportunistic infections in humans. During the last few years, it has been recognized that organisms previously identified as B. cepacia appear to be very heterogeneous and constitute a complex of phenotypically similar species, among which at least nine Burkholderia species can be differentiated by molecular methods. In patients with cystic fibrosis (CF), B. cepacia complex strains are associated with the 'cepacia syndrome', a necrotizing pneumonia with bacteraemia, which is often fatal (Isles et al., 1984). The use of B. cepacia complex strains as a fertilizer and pesticide may serve as a source of infection for patients, although there has been no proof so far that

Abbreviations: CF, cystic fibrosis; FRET, fluorescence resonance energy transfer.

The strains used in this study are listed in Supplementary Table S1 with the online version of this paper. agriculturally used strains lead to infections of CF patients (Balandreau et al., 2001; LiPuma et al., 2002). Person-toperson transmission of B. cepacia complex strains through social contact has been demonstrated (Agodi et al., 2002; Govan et al., 1993), leading to attempts to reduce this risk by segregation of patients (Thomassen et al., 1985; Muhdi et al., 1996). Due to the poor prognosis after allogenic lung transplantation (Snell et al., 1993; Chaparro et al., 2001), some transplant centres have excluded patients colonized with B. cepacia complex strains from lung transplantation programmes (Aris et al., 2001).

So far, B. cepacia genomovar I, Burkholderia multivorans (genomovar II) (Vandamme et al., 1997), Burkholderia cenocepacia (genomovar III) (Vandamme et al., 2003), Burkholderia stabilis (genomovar IV) (Vandamme et al., 2000), Burkholderia vietnamiensis (genomovar V) (Gillis et al., 1995), Burkholderia dolosa (genomovar VI) (Vermis et al., 2004; Coenye et al., 2001a), Burkholderia ambifaria (genomovar VII) (Coenye et al., 2001b), Burkholderia anthina (genomovar VIII) and Burkholderia pyrrocinia (genomovar 
IX) (Coenye et al., 2001c) have been identified within the B. cepacia complex. Epidemiological studies have indicated differences in transmission frequency and pathogenicity within the $\mathrm{CF}$ population depending upon genomovar status (Biddick et al., 2003). In particular, B. cenocepacia seems to be associated with high transmission frequency and poor prognosis (Woods et al., 2004).

Several methods have been used to identify the genomovar status of members of the B. cepacia complex. Phenotypic tests reliably separate only $B$. multivorans and $B$. stabilis (Henry et al., 2001). 23S rDNA- and 16S rDNA-based PCR assays allow the differentiation of $B$. multivorans and $B$. vietnamiensis, but not B. cepacia, B. cenocepacia or B. stabilis (LiPuma et al., 1999; Bauernfeind et al., 1999). Whitby et al. (2000) have developed a PCR algorithm of the 16S-23S rDNA spacer region that is able to separate $B$. cenocepacia and $B$. stabilis, but not B. cepacia. Conventional amplified fragment length polymorphism (AFLP) analysis can be used for $B$. cepacia complex differentiation, but is technically demanding, while automated AFLP still requires visual examination for correct identification of all isolates (Coenye et al., 1999). RFLP of $16 \mathrm{~S}$ rDNA leads to the identification of groups, but is unable to distinguish many strains of $B$. cepacia, B. cenocepacia, B. stabilis and B. pyrrocinia (Segonds et al., 1999; Vermis et al., 2002b). Discrimination of B. cepacia genomovar I, B. multivorans, B. cepacia genomovar III, B. stabilis, B. vietnamiensis and B. ambifaria is possible by RFLP analysis of the PCR-amplified recA gene using $B$. cepacia complex-specific recA primers (Mahenthiralingam et al., 2000; Coenye et al., 2001c). This approach has also been used by McDowell et al. (2001) for direct detection of B. cepacia complex strains in sputum of CF patients. Most $B$. cepacia complex genomovars can be identified by using recA-based genomovar-specific primers (Mahenthiralingam et al., 2000). Based on this approach, nested PCR assays have been described that improve the sensitivity of $B$. cepacia complex detection from sputum specimens (Moore et al.,
2002; Drevinek et al., 2002). A recent evaluation of genomovar-specific recA-based PCR tests by Vermis et al. (2002a) has revealed that PCR primers designed to be specific for B. cepacia genomovar I cross-react with B. pyrrocinia and fail to detect some genomovar I isolates. Since the rapid and reliable detection of $B$. cepacia complex organisms is important for infection control measures as well as for the clinical management of patients, a rapid method of genomovar determination suitable for daily use in the clinical laboratory is desirable.

The aim of this study was to develop a rapid test based on LightCycler technology for the differentiation of the most common B. cepacia complex culture isolates, based on the known polymorphism of the recA gene (Mahenthiralingam et al., 2000). The LightCycler technique is based on conventional PCR, but reduces the DNA amplification time by increasing the temperature transition rate through the use of air for heating and cooling (Cockerill \& Smith, 2002). Mutations within genes can be detected by sequence-specific fluorescence resonance energy transfer (FRET) probes labelled with two different fluorescence dyes that generate a fluorescence signal only when both probes bind to the target sequence. After the amplification process, a meltingcurve analysis is performed: the fluorescence is monitored with increasing temperature. A decrease in fluorescence is obtained when probes melt off. Mismatches between probe sequence and target sequence lead to a lowered melting temperature.

B. cepacia, B. multivorans, B. cenocepacia, B. stabilis and B. vietnamiensis usually comprise more than $95 \%$ of B. cepacia complex isolates in CF patients (Speert et al., 2002; Agodi et al., 2001; LiPuma et al., 2001). We therefore developed an identification protocol based on B. cepacia complex-specific LightCycler amplification of the recA locus and newly designed genomovar-specific FRET probes for the rapid detection of genomovars I-V.

Table 1. Sequences of genomovar-specific FRET probes

\begin{tabular}{|c|c|c|c|}
\hline Probe & Sequence $\left(5^{\prime}-3^{\prime}\right)$ & Orientation & Position (bp) \\
\hline I - sensor & GCA GTT CCG GCA CAT TCA C-fluorescein & Antisense & $329-346$ \\
\hline II - sensor & GCC GAG GAC ATC CAG GTC G-fluorescein & Sense & $100-118$ \\
\hline III-A - anchor & LightCycler Red 640-CGT GAA CGT GCC GGA GCT GC & Sense & $327-346$ \\
\hline III-B - sensor & CTG CAA GTC ATC GCT GAA CTG C-fluorescein & Sense & $232-253$ \\
\hline IV - anchor & TGA TCT CGC AGC CGG ACA CCG-fluorescein & Sense & $347-367$ \\
\hline IV - sensor & LightCycler Red 705-CGA GCA GGC GCT TGA AAT CAC & Sense & $369-389$ \\
\hline $\mathrm{V}-$ anchor & LightCycler Red 705-AGG TCG TCT CCA CGG GCT CGC T & Sense & $114-134$ \\
\hline$V-$ sensor & GGC GAC GTG AAG GAA GAC ATC-fluorescein & Sense & $91-111$ \\
\hline
\end{tabular}




\section{METHODS}

Bacterial strains and template preparation. Strains of B. cepacia genomovar I, B. multivorans (II), B. cenocepacia lineages III-A and III-B, B. stabilis (IV) and B. vietnamiensis (V) were received from the Belgian Coordinated Collections of Microorganisms/Laboratorium voor Microbiologie Universiteit Gent (BCCM/LMG) Bacteria Collection or were clinical isolates of Hannover Medical School, Hannover, Germany, which were tentatively identified as B. cepacia after growth on OFBL agar (Henry et al., 1997) and determination of biochemical profiles using API 20NE. These strains were further identified by SDS-PAGE of whole-cell proteins and, if necessary, by recA RFLP as described by Coenye et al. (2001b). All strains, including non-B. cepacia complex organisms used in this study, are listed in Supplementary Table S1 with the online version of this paper.
Bacteria were grown overnight on Columbia blood agar plates at $37^{\circ} \mathrm{C}$. Ten colonies were then mixed with $1 \mu \mathrm{l}$ DNA-free water. Two microlitres of this suspension served as template. No further DNA extraction was performed. In addition to non-B. cepacia complex bacterial suspensions, DNA-free water also served as a negative control.

LightCycler protocol. A LightCycler system (Roche Molecular Biochemicals) and FRET probes (TIB MOLBIOL) labelled with different LightCycler Red dyes (640 and $705 \mathrm{~nm}$ ) were used. FRET probes were designed to show a perfect match only to the corresponding genomovar. When FRET probes bind to their target sequence, a fluorescence signal is detected by the system. If denaturation occurs, a loss of fluorescence is observed. Therefore, if the target sequence shows a mismatch, the melting temperature of FRET
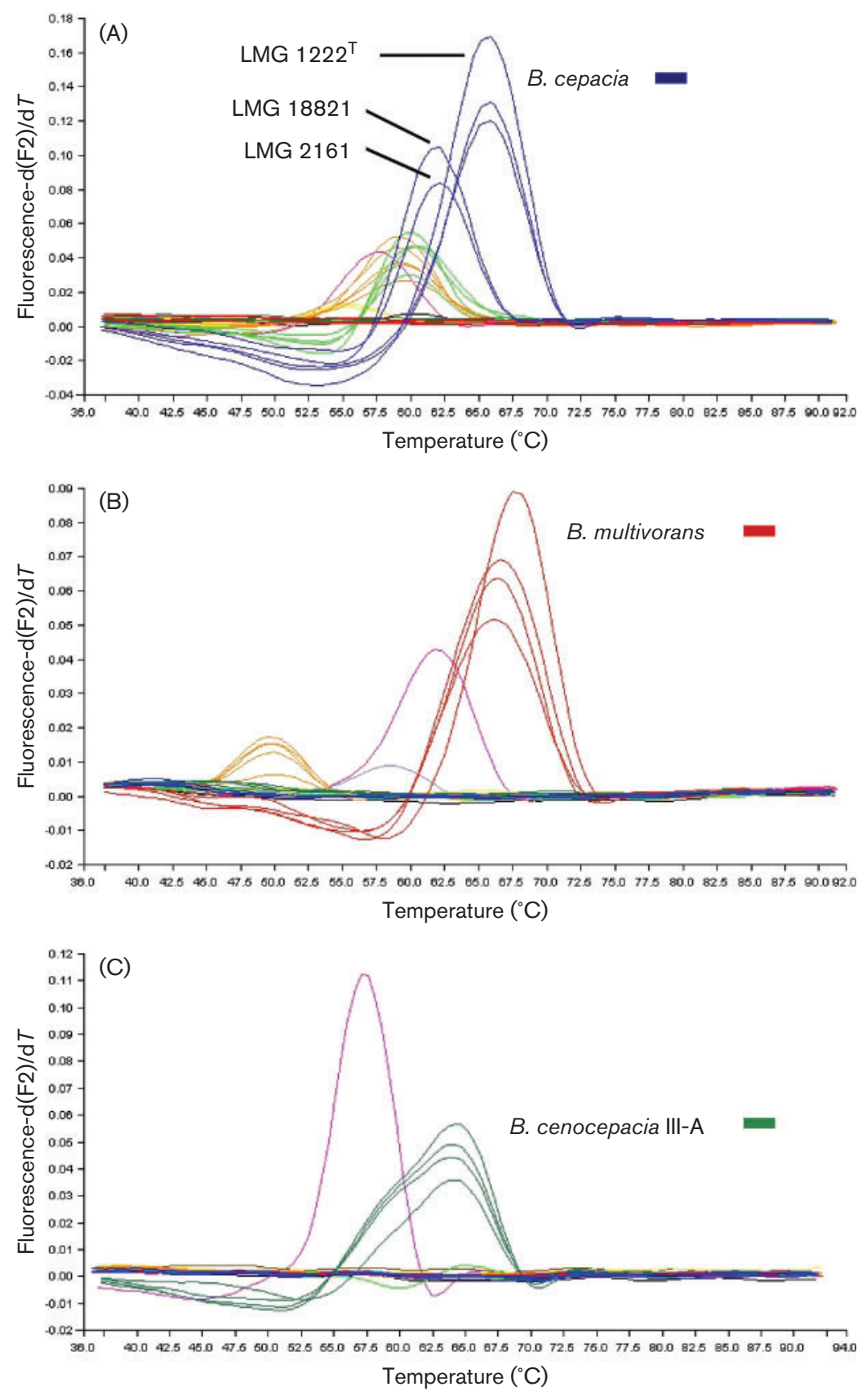

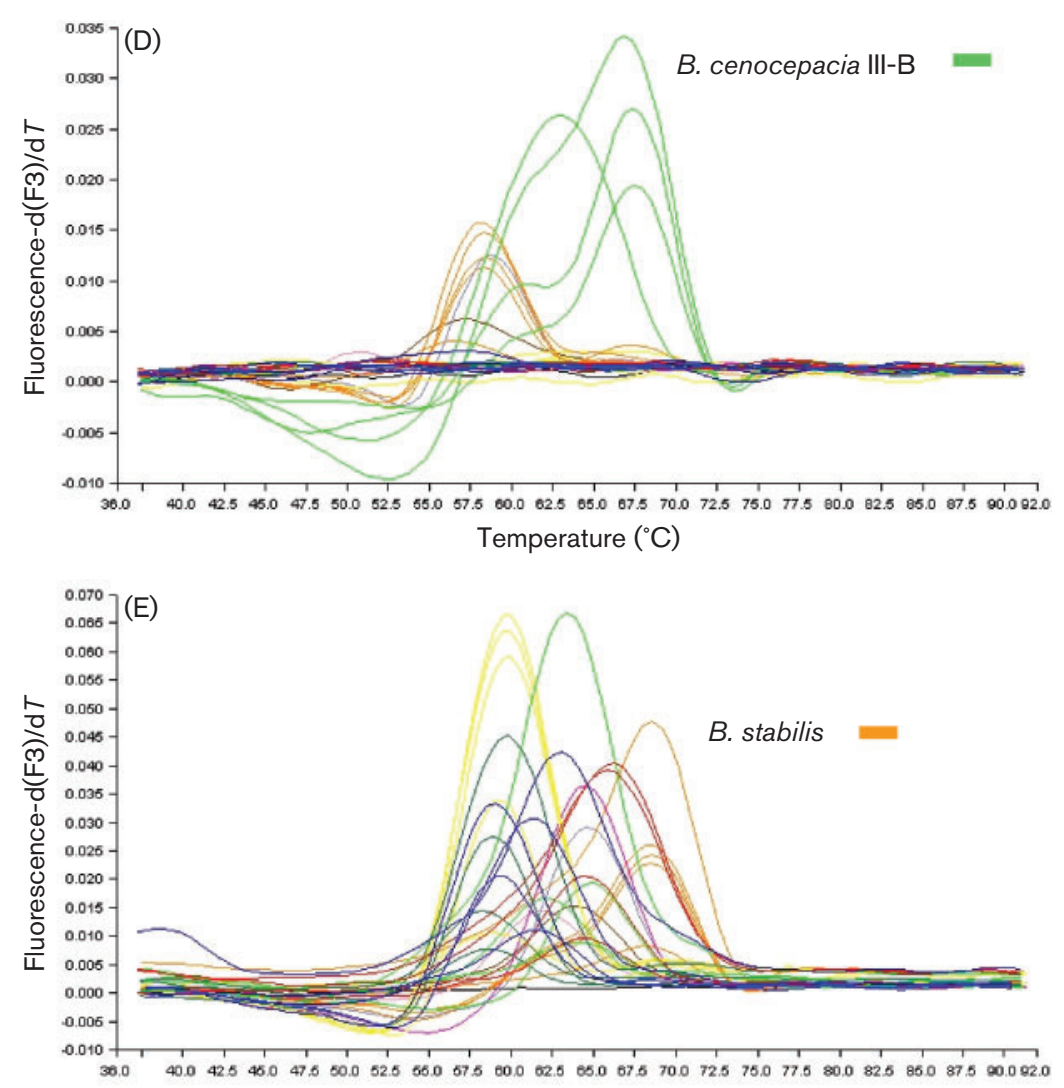

Temperature $\left({ }^{\circ} \mathrm{C}\right)$

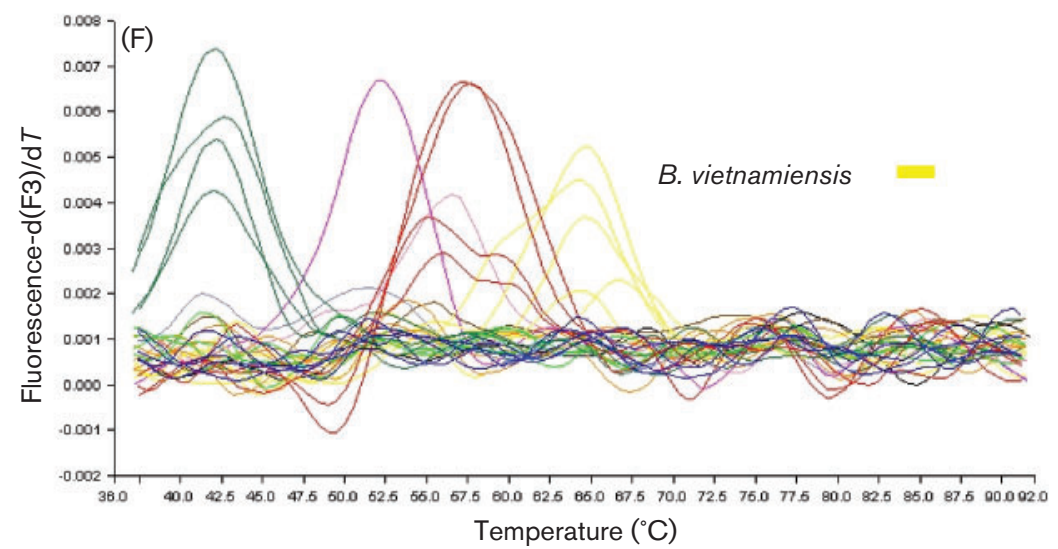

Fig. 1. B. cepacia complex genomovar identification using genomovar-specific FRET probes. Screen captures of melting-peak analyses are shown. The melting-curve analysis is displayed as the first negative derivative of the fluorescence $(-d F / d T)$ versus temperature. F2 refers to channel 2, which was used to measure signals from LightCycler Red 640 at $640 \mathrm{~nm}$ (A-C). F3 refers to channel 3, which measures signals from LightCycler Red 705 at $705 \mathrm{~nm}$ (D-F). The identification with the specific FRET probes of representative strains of $B$. cepacia (five strains) (A), B. multivorans (four strains) (B), B. cenocepacia lineage III-A (four strains) (C), B. cenocepacia lineage III-B (four strains) (D), B. stabilis (five strains) (E) and $B$. vietnamiensis (five strains) $(F)$ is shown. B. dolosa (genomovar VI) (brown), B. ambifaria (genomovar VII) (purple), B. anthina (genomovar VIII) (grey) and B. pyrrocinia (genomovar IX) (pink), and DNA-free water (black), served as controls. Detection probes showed the highest melting temperature with representative strains of the corresponding genomovar, while other genomovars showed lower non-specific melting peaks or no peaks at all. probes is lowered. Visualization of the melting temperature at which the probe melted from the amplicon from the loss of fluorescence that occurred was done by plotting $-\mathrm{d}(\mathrm{F} 2) / \mathrm{d} T$ against temperature.

Amplification of the B. cepacia complex recA gene was performed using a total volume of $18 \mu \mathrm{l}$ of the ready-to-use reaction mixture of the Fast Start DNA Master Hybridization Probe kit (Roche Diagnostics), supplemented with $4 \mathrm{mM} \mathrm{MgCl} 2,10 \mathrm{pM}$ of each primer BCR1 and BCR2 (MWG-Biotech) specific for the B. cepacia complex recA gene, as described by Mahenthiralingam et al. (2000) (500 nM final concentration), and 2 pM of two probe pairs for genomovar determination (100 nM final concentration). Two microlitres of template as described above were added for a total sample volume of $20 \mu \mathrm{l}$ in each glass capillary.

After an initial denaturation step $\left(95^{\circ} \mathrm{C}, 10 \mathrm{~min}\right), 45$ cycles consisting of denaturation $\left(95^{\circ} \mathrm{C}, 10 \mathrm{~s}\right.$ each), annealing (reached with a touch-down from 66 to $60{ }^{\circ} \mathrm{C}$ at $1{ }^{\circ} \mathrm{C}$ per cycle, $10 \mathrm{~s}$ each) and elongation $\left(72^{\circ} \mathrm{C}, 20 \mathrm{~s}\right)$ were run for recA gene amplification. After a final denaturation $\left(95^{\circ} \mathrm{C}, 30 \mathrm{~s}\right)$, melting-curve analysis from 40 up to $75^{\circ} \mathrm{C}$ was done, measuring fluorescence at 640 and $705 \mathrm{~nm}$ continuously. The temperature transition rate was $20^{\circ} \mathrm{C} \mathrm{s}^{-1}$ for all changes in temperature, except for melting-curve analysis, for which the rate was lowered to $0 \cdot 1^{\circ} \mathrm{C} \mathrm{s}^{-1}$.

The sequences of FRET probes used for genomovar determination are listed in Table 1. Probe pairs for detection of genomovars I, II and III-A were labelled with LightCycler Red 640, and probe pairs for genomovars III-B, IV and V were labelled with LightCycler Red 705, respectively. Colour compensation software was used when FRET probes with labels of different wavelengths were tested simultaneously. The sequences of hybridization probes were based on the alignment of published recA sequences of defined B. cepacia complex genomovars 
I-IX (GenBank accession nos AF143774-AF143795, AF143798AF143799, AF323985, AF456003, AF456005-AF456007, AF456012AF456014, AF456021, AF456027-AF456033, AF456045, AF456055, AF456058, AF456060, AF456070, AF456076-AF456077, AF456093, AF456097, AF456102, AF456104, AF456106-AF456108 and AJ544692) using DNA Star Windows 32 MegAlign 4.00 software.

To determine the sensitivity of our LightCycler protocol, a template suspension was prepared as described above. Serial dilution of the template suspension using DNA-free water was performed. Diluted probes then were used for LightCycler detection. In addition, diluted probes were used to calibrate LightCycler detection against bacterial c.f.u. after growth overnight on Columbia blood agar plates at $37^{\circ} \mathrm{C}$.

\section{RESULTS AND DISCUSSION}

We first tested amplification of the recA gene with primers BCR1 and BCR2 (Mahenthiralingam et al., 2000; McDowell et al., 2001) in strains belonging to B. cepacia complex genomovars I, II, III-A, III-B, IV and V using LightCycler technology. Under these experimental conditions, primers BCR1 and BCR2 proved to be specific for all these genomovars, as described for conventional PCR (Mahenthiralingam et al., 2000), and led to a PCR product of $1043 \mathrm{bp}$ visualized by conventional gel electrophoresis, whereas non- $B$. cepacia complex members did not show an amplification product of this size (not shown).

After alignment of recA sequences from genomovar I to genomovar IX, genomovar-specific portions were used to design FRET probes. Sequences are shown in Table 1. Using these probes, the genomovar status of all 39 B. cepacia complex strains belonging to genomovars I, II, III-A, III-B, $\mathrm{IV}$ and $\mathrm{V}$ was correctly identified by melting-curve analysis. Fig. 1 shows the specific peak loss of fluorescence of the detection probes of four representative strains of $B$. multivorans (Fig. 1B), B. cenocepacia III-A (Fig. 1C) and B. cenocepacia III-B (Fig. 1D), and of five strains of $B$. cepacia (Fig. 1A), B. stabilis (Fig. 1E) and B. vietnamiensis (Fig. 1F). Each probe pair was tested against members of all other genomovars and lineages as well as against the non- $B$. cepacia complex strains listed above, in order to exclude possible interference. For all other genomovars, including lineages III-C and III-D, only non-specific melting points at significantly lower temperatures, or no peaks at all, were observed (data not shown).

The observed melting-point differences between strains within one genomovar (Fig. 1) are most likely due to point mutations in the portion of the recA sequence used for hybridization. For example, differences of peak melting point between the B. cepacia strains LMG $1222^{\mathrm{T}}$ (GenBank accession no. AF143786) and strains LMG 18821 and LMG 2161 (GenBank accession nos AF143787 and AF143788), as shown in Fig. 1(A), are due to a single nucleotide mismatch at position 339. We observed a similar phenomenon for $B$. cenocepacia III-B (Fig. 1D) and B. vietnamiensis (Fig. 1F). However, the differences in the results of the melting-curve analysis were still sufficiently large to distinguish these genomovars from all other genomovars. Our LightCycler method could detect as few as 5 c.f.u. of all genomovar I-V strains tested. Fig. 2 shows a representative assay for $B$. cepacia lineage III-B LMG 16659.

In conclusion, we were able to develop a rapid-cycle PCR system that allowed determination of B. cepacia complex genomovars $\mathrm{I}-\mathrm{V}$ from culture isolates within about $1 \mathrm{~h}$ using genomovar-specific FRET probes. This approach could also discriminate genomovar I from B. pyrrocinia (genomovar IX), since there was no melting-point signal

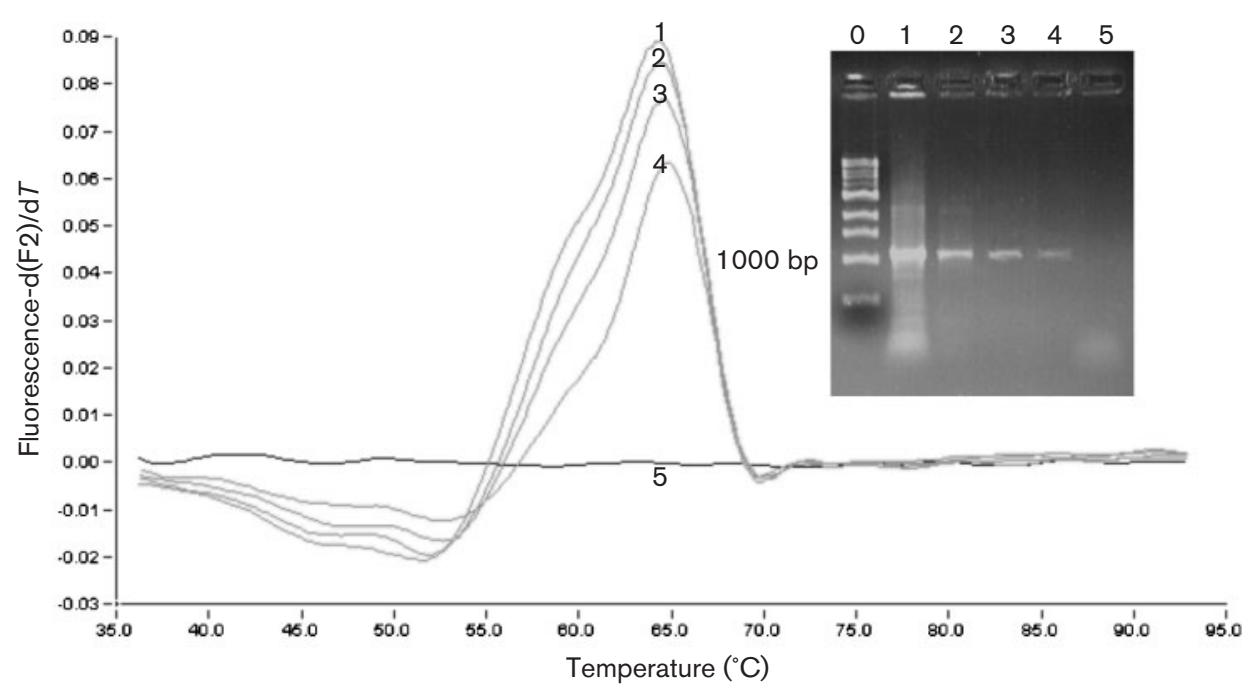

Fig. 2. Sensitivity of $B$. cepacia complex genomovar identification. Screen captures of melting-peak analyses and gel electrophoresis of amplicons of a representative strain (B. cenocepacia lineage III-B LMG 16659) are shown. Five c.f.u. of $B$. cepacia complex strains were reproducibly detected in genomovars I-V. Key: 0, 1 kb DNA ladder; 1, 100 c.f.u.; 2, 50 c.f.u.; 3 , 10 c.f.u.; 4, 5 c.f.u.; 5, no template. 
with a genomovar I-specific FRET probe and B. pyrrocinia, as shown in Fig. 1(A). This discrimination is not possible by conventional genomovar-specific PCR (Vermis et al., 2002a). Our method is based on the use of commercially available components under standardized conditions. It should therefore enable any clinical laboratory with access to LightCycler technology to distinguish between these genomovars, which exhibit different transmission frequences and probably different pathogenic potential (Agodi et al., 2001; Speert et al., 2002; LiPuma et al., 2001). Rapid-cycle realtime PCR has not only been used for the differentiation of a variety of pathogens from cultures but also for direct detection from clinical specimens. In first experiments, using the LightCycler technology, we have been able to detect directly genomovars I-V in CF sputum specimens seeded with the respective organisms (data not shown). Future studies will have to evaluate the sensitivity and specificity of this method for clinical specimens.

\section{ACKNOWLEDGEMENTS}

We thank D. Bitter-Suermann for his continuous interest and support of this study.

\section{REFERENCES}

Agodi, A., Mahenthiralingam, E., Barchitta, M., Giannino, V., Sciacca, A. \& Stefani, S. (2001). Burkholderia cepacia complex infection in Italian patients with cystic fibrosis: prevalence, epidemiology, and genomovar status. J Clin Microbiol 39, 2891-2896.

Agodi, A., Barchitta, M., Giannino, V. \& 8 other authors (2002). Burkholderia cepacia complex in cystic fibrosis and non-cystic fibrosis patients: identification of a cluster of epidemic lineages. J Hosp Infect 50, 188-195.

Aris, R. M., Routh, J. C., LiPuma, J. J., Heath, D. G. \& Gilligan, P. H. (2001). Lung transplantation for cystic fibrosis patients with Burkholderia cepacia complex. Survival linked to genomovar type. Am J Respir Crit Care Med 164, 2102-2106.

Balandreau, J., Viallard, V., Cournoyer, B., Coenye, T., Laevens, S. \& Vandamme, P. (2001). Burkholderia cepacia genomovar III is a common plant-associated bacterium. Appl Environ Microbiol 67, 982-985.

Bauernfeind, A., Schneider, I., Jungwirth, R. \& Roller, C. (1999). Discrimination of Burkholderia multivorans and Burkholderia vietnamiensis from Burkholderia cepacia genomovars I, III, and IV by PCR. J Clin Microbiol 37, 1335-1339.

Biddick, R., Spilker, T., Martin, A. \& LiPuma, J. J. (2003). Evidence of transmission of Burkholderia cepacia, Burkholderia multivorans and Burkholderia dolosa among persons with cystic fibrosis. FEMS Microbiol Lett 228, 57-62.

Chaparro, C., Maurer, J., Gutierrez, C. \& 8 other authors (2001). Infection with Burkholderia cepacia in cystic fibrosis: outcome following lung transplantation. Am J Respir Crit Care Med 163, 43-48.

Cockerill, F. R. \& Smith, T. F. (2002). Rapid-cycle real-time PCR: a revolution for clinical microbiology. ASM News 68, 77-83.

Coenye, T., Schouls, L. M., Govan, J. R., Kersters, K. \& Vandamme, P. (1999). Identification of Burkholderia species and genomovars from cystic fibrosis patients by AFLP fingerprinting. Int $J$ Syst Bacteriol 49, 1657-1666.
Coenye, T., LiPuma, J. J., Henry, D., Hoste, B., Vandemeulebroecke, K., Gillis, M., Speert, D. P. \& Vandamme, P. (2001a). Burkholderia cepacia genomovar VI, a new member of the Burkholderia cepacia complex isolated from cystic fibrosis patients. Int J Syst Evol Microbiol 51, 271-279.

Coenye, T., Mahenthiralingam, E., Henry, D., LiPuma, J. J., Laevens, S., Gillis, M., Speert, D. P. \& Vandamme, P. (2001b). Burkholderia ambifaria sp. nov., a novel member of the Burkholderia cepacia complex including biocontrol and cystic fibrosis-related isolates. Int J Syst Evol Microbiol 51, 1481-1490.

Coenye, T., Vandamme, P., Govan, J. R. \& LiPuma, J. J. (2001c). Taxonomy and identification of the Burkholderia cepacia complex. J Clin Microbiol 39, 3427-3436.

Drevinek, P., Hrbackova, H., Cinek, O., Bartosova, J., Nyc, O., Nemec, A. \& Pohunek, P. (2002). Direct PCR detection of Burkholderia cepacia complex and identification of its genomovars by using sputum as source of DNA. J Clin Microbiol 40, 3485-3488.

Gillis, M., Van, T. V., Bardin, R. \& 7 other authors (1995). Polyphasic taxonomy in the genus Burkholderia leading to an emended description of the genus and proposition of Burkholderia vietnamiensis sp. nov. for N2-fixing isolates from rice in Vietnam. Int J Syst Bacteriol 45, 274-289.

Govan, J. R., Brown, P. H., Maddison, J., Doherty, C. J., Nelson, J. W., Dodd, M., Greening, A. P. \& Webb, A. K. (1993). Evidence for transmission of Pseudomonas cepacia by social contact in cystic fibrosis. Lancet 342, 15-19.

Henry, D. A., Campbell, M. E., LiPuma, J. J. \& Speert, D. P. (1997). Identification of Burkholderia cepacia isolates from patients with cystic fibrosis and use of a simple new selective medium. J Clin Microbiol 35, 614-619.

Henry, D. A., Mahenthiralingam, E., Vandamme, P., Coenye, T. \& Speert, D. P. (2001). Phenotypic methods for determining genomovar status of the Burkholderia cepacia complex. J Clin Microbiol 39, 1073-1078.

Isles, A., Maclusky, I., Corey, M., Gold, R., Prober, C., Fleming, P. \& Levison, H. (1984). Pseudomonas cepacia infection in cystic fibrosis: an emerging problem. J Pediatr 104, 206-210.

LiPuma, J. J., Dulaney, B. J., McMenamin, J. D., Whitby, P. W., Stull, T. L., Coenye, T. \& Vandamme, P. (1999). Development of rRNAbased PCR assays for identification of Burkholderia cepacia complex isolates recovered from cystic fibrosis patients. J Clin Microbiol 37, 3167-3170.

LiPuma, J. J., Spilker, T., Gill, L. H., Campbell, P. W., III, Liu, L. \& Mahenthiralingam, E. (2001). Disproportionate distribution of Burkholderia cepacia complex species and transmissibility markers in cystic fibrosis. Am J Respir Crit Care Med 164, 92-96.

LiPuma, J. J., Spilker, T., Coenye, T. \& Gonzalez, C. F. (2002). An epidemic Burkholderia cepacia complex strain identified in soil. Lancet 359, 2002-2003.

Mahenthiralingam, E., Bischof, J., Byrne, S. K., Radomski, C., Davies, J. E., Av-Gay, Y. \& Vandamme, P. (2000). DNA-based diagnostic approaches for identification of Burkholderia cepacia complex, Burkholderia vietnamiensis, Burkholderia multivorans, Burkholderia stabilis, and Burkholderia cepacia genomovars I and III. J Clin Microbiol 38, 3165-3173.

McDowell, A., Mahenthiralingam, E., Moore, J. E. \& 8 other authors (2001). PCR-based detection and identification of Burkholderia cepacia complex pathogens in sputum from cystic fibrosis patients. J Clin Microbiol 39, 4247-4255.

Moore, J. E., Xu, J., Millar, B. C., Crowe, M. \& Elborn, J. S. (2002). Improved molecular detection of Burkholderia cepacia genomovar III and Burkholderia multivorans directly from sputum of patients with cystic fibrosis. J Microbiol Methods 49, 183-191. 
Muhdi, K., Edenborough, F. P., Gumery, L., O'Hickey, S., Smith, E. G., Smith, D. L. \& Stableforth, D. E. (1996). Outcome for patients colonised with Burkholderia cepacia in a Birmingham adult cystic fibrosis clinic and the end of an epidemic. Thorax 51, 374-377.

Segonds, C., Heulin, T., Marty, N. \& Chabanon, G. (1999). Differentiation of Burkholderia species by PCR-restriction fragment length polymorphism analysis of the $16 \mathrm{~S}$ rRNA gene and application to cystic fibrosis isolates. J Clin Microbiol 37, 2201-2208.

Snell, G. I., de Hoyos, A., Krajden, M., Winton, T. \& Maurer, J. R. (1993). Pseudomonas cepacia in lung transplant recipients with cystic fibrosis. Chest 103, 466-471.

Speert, D. P., Henry, D., Vandamme, P., Corey, M. \& Mahenthiralingam, E. (2002). Epidemiology of Burkholderia cepacia complex in patients with cystic fibrosis, Canada. Emerg Infect Dis 8, 181-187.

Thomassen, M. J., Demko, C. A., Klinger, J. D. \& Stern, R. C. (1985). Pseudomonas cepacia colonization among patients with cystic fibrosis. A new opportunist. Am Rev Respir Dis 131, 791-796.

Vandamme, P., Holmes, B., Vancanneyt, M. \& 8 other authors (1997). Occurrence of multiple genomovars of Burkholderia cepacia in cystic fibrosis patients and proposal of Burkholderia multivorans sp. nov. Int J Syst Bacteriol 47, 1188-1200.

Vandamme, P., Mahenthiralingam, E., Holmes, B., Coenye, T., Hoste, B., De Vos, P., Henry, D. \& Speert, D. P. (2000). Identification and population structure of Burkholderia stabilis sp. nov. (formerly Burkholderia cepacia genomovar IV). J Clin Microbiol 38, 1042-1047.
Vandamme, P., Holmes, B., Coenye, T., Goris, J., Mahenthiralingam, E., LiPuma, J. J. \& Govan, J. R. (2003). Burkholderia cenocepacia sp. nov. - a new twist to an old story. Res Microbiol 154, 91-96.

Vermis, K., Coenye, T., Mahenthiralingam, E., Nelis, H. J. \& Vandamme, P. (2002a). Evaluation of species-specific recA-based PCR tests for genomovar level identification within the Burkholderia cepacia complex. J Med Microbiol 51, 937-940.

Vermis, K., Vandekerckhove, C., Nelis, H. J. \& Vandamme, P. A. (2002b). Evaluation of restriction fragment length polymorphism analysis of $16 \mathrm{~S}$ rDNA as a tool for genomovar characterisation within the Burkholderia cepacia complex. FEMS Microbiol Lett 214, $1-5$.

Vermis, K., Coenye, T., LiPuma, J. J., Mahenthiralingam, E., Nelis, H. J. \& Vandamme, P. (2004). Proposal to accommodate Burkholderia cepacia genomovar VI as Burkholderia dolosa sp. nov. Int J Syst Evol Microbiol 54, 689-691.

Whitby, P. W., Carter, K. B., Hatter, K. L., LiPuma, J. J. \& Stull, T. L. (2000). Identification of members of the Burkholderia cepacia complex by species-specific PCR. J Clin Microbiol 38, 2962-2965.

Woods, C. W., Bressler, A. M., LiPuma, J. J., Alexander, B. D., Clements, D. A., Weber, D. J., Moore, C. M., Reller, L. B. \& Kaye, K. S. (2004). Virulence associated with outbreak-related strains of Burkholderia cepacia complex among a cohort of patients with bacteremia. Clin Infect Dis 38, 1243-1250. 